12. Papciak, D. The use of biofiltration process to remove organic matter from groundwater [Text] / D. Papciak, J. Kaleta, A. Puszkarewicz, B. Tchórzewska-Cieślak // Journal of Ecological Engineering. - 2016. - Vol. 17, Issue 3. - P. 119-124. doi: 10.12911/22998993/63481

13. Prigun, I. V. Tehnologii udalenija ammiaka [Ammonia removal technology] [Text] / I. V. Prigun, M. S. Krasnov // Water Treatment,Water Conditioning,Water Supply. - 2009. - Vol. 8. - P. 36-41.

14. Kuberis, E. A. Environmental monitoring and analysis of quality of the Nizhny Novgorod region ground water with the development of the technologies of their filtration [Text] / E. A. Kuberis, E. A. Gorbachov // Journal of the Geographical Institute Jovan Cvijic, SASA. - 2014. - Vol. 64, Issue 2. - P. 177-191. doi: 10.2298/ijgi1402177k

15. Patent of Ukraine. C02F 1/64, 1/52, 1/72. № 107844. Method of cleaning groundwater from organic and sustainable forms of iron organic compounds [Text] / Kvartenko O. M. - declared: 28.02.13; published: 25.02.15. Bul. 4. - 7 p.

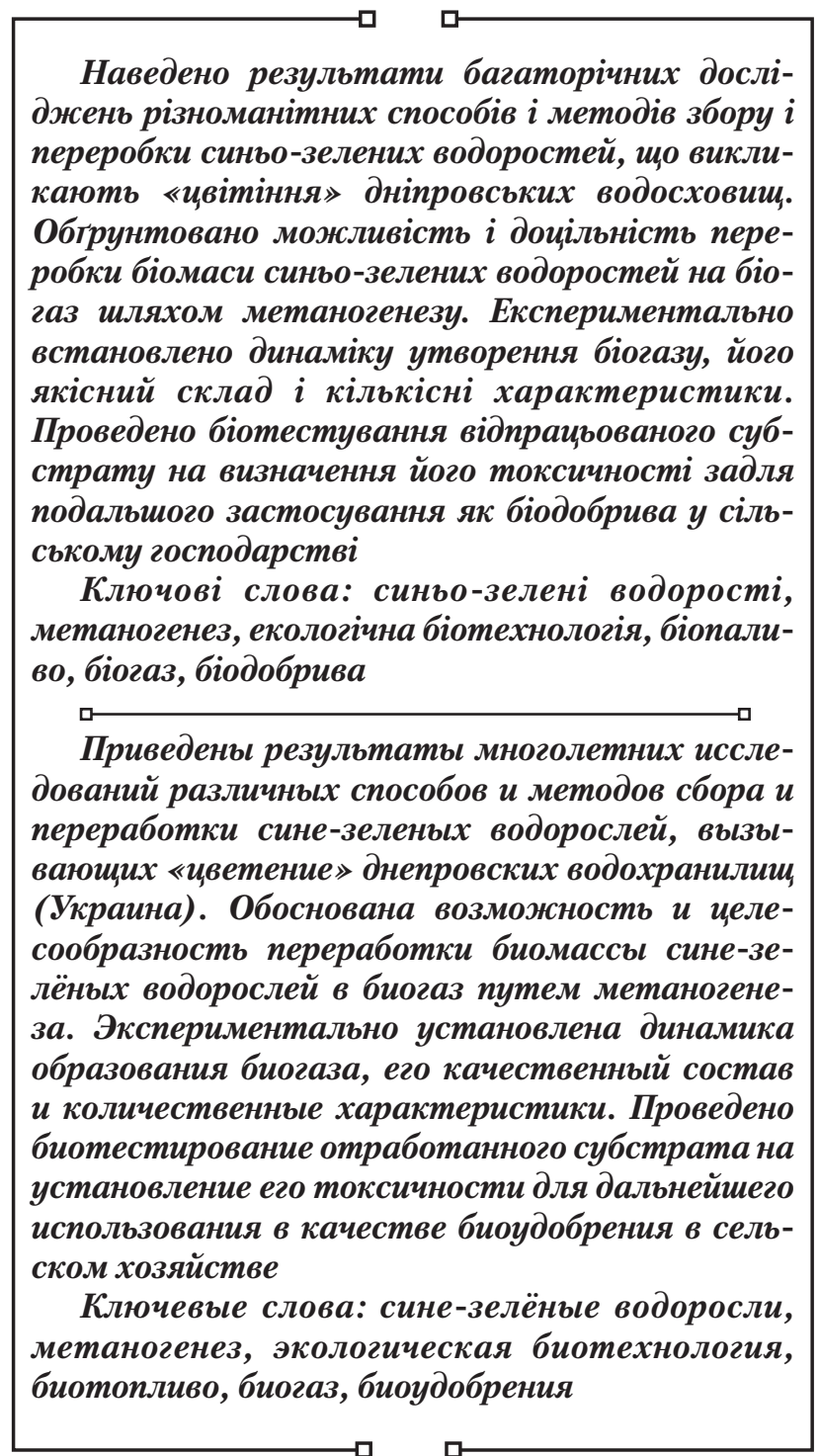

1. Introduction

Financial instability of the world economy as a result of an energy crisis brings into focus the search for new nonconventional (alternative) energy sources. Among others, these include solar energy, accumulated in the biomass of photosynthetic (autotrophic) plants (so-called solar energy bioconservation).

It should be noted that to date a certain portion of the energy potential of land-based plant biomass is already utilized by mankind. A sixth of the energy consumed is produced from $\frac{\text { UDC } 602.3: 582.26(045)}{\text { DOI: } 10.15587 / 1729-4061.2016 .79789}$

\section{THE BIOTECHNOLOGICAL WAYS OF BLUE-GREEN ALGAE COMPLEX PROCESSING}

V. Nykyforov

Doctor of Biological Science, Professor, First Vice-Rector* E-mail:v-nik@kdu.edu.ua

M. Ma l ov a n y y

Doctor of Technical Science, Professor, Head of Department

Department of Ecology and Sustainable Environmental Management Lviv Polytechnic National University S. Bandera str., 12, Lviv, Ukraine, 79013

E-mail: mmal@Ip.edu.ua

T. Kozlovs'ka

PhD, Associate Professor*

E-mail: tfk58@kdu.edu.ua

O. Novok hatko

$\mathrm{PhD}$, Associate Professor, Head of Department*

E-mail: krnubiotechnology@gmail.com

S. Digtiar

Senior Lector*

E-mail: sergiusvictor@gmail.com

*Department of Biotechnology and Human Health Mykhailo Ostrohradskyi Kremenchuk National University Pershotravneva str., 20, Kremenchuk, Ukraine, 39600

agricultural and other phytomass. This is equivalent to the daily use of more than 4 million tons of oil. However, the biomass of aquatic microorganisms and phytoplankton (algae) is not in demand at all [1].

Plants utilize on average about $0.1 \%$ of the total amount of solar radiation annually reaching the Earth's surface. This value is almost 10 times greater than world energy consumption. Therefore, there is an idea of using the biogas - the fuel produced from organic matter by means of bioconversion - biomethanogenesis, or methane "fermentation" [2]. 
The most promising accumulators of solar energy were algae that improve its efficiency up to $3-5 \%$. Thus, the maximum efficiency of photosynthesis in the blue-green algae is $20 \%$, which is 200 times higher than the average photosynthesis efficiency in land-based plants.

The most cost-effective process is methanation of the biomass of the wastewater-grown algae (treatment cost savings), as well as collected during their mass development ("bloom") under natural conditions (environmental cost savings).

The productivity of plants for methane production from the wastewater-grown algae is $50-80 \mathrm{t} / \mathrm{ha}$ of dry biomass per year, which gives from 75 to 120 thousand $\mathrm{kW} / \mathrm{h}$ of electric power. Methane "fermentation" waste is a rich source of feed and can be used in forestry and agriculture as fertilizers [3].

The energy produced by algae photosynthesis with subsequent conversion into gas is considered competitive alongside nuclear energy. Moreover, this source of energy is absolutely safe - does not cause environmental imbalance, does not lead to radioactive or thermal pollution, allows to manage water self-purification processes and save natural resources. Thus, algae photosynthesis is an additional source of biologically active substances and fertilizers.

Besides, limiting the mass development of the blue-green algae (BGA) in artificial reservoirs can reduce the level of environmental risk associated with "bloom" outbreaks. This leads to significant economic losses due to violation of the hydrochemical, hydrobiological regimes of reservoirs, inhibition of aquatic organisms and inhabitants of adjacent biotopes.

Therefore, the use of BGA during their mass development in the waters of the Dnieper cascade reservoirs to produce biofuels $[4,5]$ and biofertilizers with subsequent deep processing will provide not only an additional source of energy, but also improve water quality and environmental safety in coastal areas.

\section{Literature review and problem statement}

The problem of removing excess BGA from reservoirs shall be considered from a utilitarian point of view, i. e. as a natural producer of the biomass containing valuable food, feed, medical, pharmaceutical, perfumery, agricultural and forestry, as well as technical substances [4,5].

However, it shall be emphasized that one of the reasons for sharp water quality deterioration in artificial reservoirs, especially during their "bloom", is a toxic effect of BGA due to their toxins - alkaloids, polypeptides, and pteridines. They cause mass death of aquatic organisms, waterfowl, and pets.

Allergies, conjunctivitis, food poisoning developin humans in cases of poisoning by toxins of these algae. This is due to the high biological activity of the main toxin Microcystis aeruginosa (Kützing) Kützing - microcystin. In this regard, there is a need for preventive and detoxifying measures in the drinking water catchments and water sanitary protection zones of settlements. It is necessary to emphasize that to date the technology of water purification from toxins is complex and, therefore, expensive.

The main factor causing the "bloom" of water bodies is solar activity. It was found that in the years of low solar activity, "bloom" occurs at the end of May-June, reaching a peak in July-August and lasts until October. The BGA biomass concentration is characterized by higher parameters in reservoirs, especially in "bloom" spots. Under the active sun, "bloom" is shifted to autumn, and the phytoplankton bio- mass is $3-5$ times less, which reduces biological pollution of a reservoir [6]. Consequently, a reliable forecast of "bloom", as well as knowledge of the factors that regulate the level and intensity of the toxin formation are urgent and necessary.

The products of secondary biological water pollution as a result of the BGA phytomass biodegradation also include greenhouse gases - carbon dioxide and methane. It is known [7] that in a closed littoral there are two summer peaks of $\mathrm{CH}_{4}$ formation due to seasonal fluxes of organic matter. The first occurs during the summer outbreaks of mass development of phytoplankton, and the second - at the end of the growing season of higher aquatic plants within (1.17-5.21) $10^{-6} \mathrm{dm}^{3}$ of $\mathrm{CH}_{4} / \mathrm{dm}^{3}$ per day. During this period the water column was enriched with methane in the amount of $(0.9-12.6) \cdot 10^{-6} \mathrm{dm}^{3}$ of $\mathrm{CH}_{4} / \mathrm{dm}^{3}$.

Microbiological processes of methane generation in reservoirs are universal in occurrence though with sharp space-time fluctuations, with the efficiency of $0.01-2410^{-6} \mathrm{dm}^{3}$ of $\mathrm{CH}_{4} / \mathrm{dm}^{3}$ per day. The consumption of oxygen reaches $10 \%$ BOD1, and organic carbon - (3.5-9.7) $10^{-6} \mathrm{dm}^{3}$ per day [7].

Thus, the BGA biomass extraction from the "blooming" reservoirs of the Dnieper cascade will allow Ukraine to implement the conditions of the Kyoto Protocol to the UN Framework Convention on Climate Change (Rio de Janeiro, 1992) [8], as well as adhere to the Directive 2000/60/EC of the European Parliament and of the Council establishing a framework for Community action in the field of water policy (Brussels, 2000) [9]. From this perspective, the implementation of the target comprehensive research program of NAS of Ukraine "Biomass as a fuel" in Ukraine is very effective [10].

\section{Goals and objectives}

The goal of the research provides for comprehensive studies on the development of environment-friendly biotechnology for the production of biofuels and biofertilizers from the BGA biomass.

To achieve this goal, the following tasks were set:

- to determine the species composition of cyanogenobacteria and microorganisms involved in biodegradation and bioconversion of the seston collected during water "bloom";

- to examine the qualitative and quantitative dynamics of biogas production from BGA;

- to determine a mass fraction of the basic chemical elements of the spent substrate to be used as an organic-mineral fertilizer;

- to offer biotechnological ways of BGA complex processing and identify the industries of application of its products.

\section{Materials and methods}

\section{1. Electron and light microscopy}

For microscopy of objects with a size less than 10 microns (small cyanogenobacteria and methanobacteria), a measuring scanning electron microscope (SEM-106 I) was used, which is included in the State Register of Ukraine with the following parameters [11]:

- resolution in high- and low-vacuum mode -4 and $6 \mathrm{~nm}$, respectively;

- maximum image size - $1280 \times 960 \mathrm{px}$;

- pressure adjustment range in the chamber - 1-270 $\mathrm{Pa}$;

- accelerating pressure range $-0.5-30.0 \mathrm{~kW}$; 
- magnification adjustment range $-15-3 \cdot 10^{5}$;

- maximum object size $-50 \mathrm{~mm}$.

For microscopy of objects with a size greater than $10 \mathrm{mi}-$ crons (large cyanogenobacteria or colonies of small species), the Ningbo Shengheng XS-3330s light microscope (China) with the micro med video adapter and the "ISCapture" image processing computer program (China) was used.

\section{2. Determination of elemental composition of algal} biomass

Measurement of the mass fraction (\%) of the basic chemical elements in the BGA dry biomass was performed using the EXPERT 3L X-ray fluorescence analyzer (XRFA). It implements the method of energy-dispersive elemental analysis. It involves the initiation of characteristic radiation of the sample atoms by photons of the inhibitory spectrum of a low-power X-ray tube with subsequent registration by the semiconductor PIN-detector.

Basic EXPERT 3L XRFA parameters [12]:

- the range of the measured chemical elements (control range) - from magnesium $\left({ }_{12} \mathrm{Mg}\right)$ to uranium $\left({ }_{92} \mathrm{U}\right)$;

- the range of measurement of mass fractions (concentrations) of elements $-0.01 \%-99.90 \%$;

- ramp-up time of the plant - no more than 5 min;

- ambient temperature $-+15 \ldots+45{ }^{\circ} \mathrm{C}$;

- relative humidity - no more than $80 \%$ over the entire temperature range;

- equivalent dose rate of X-ray radiation on the instrument surface does not exceed $74 \mathrm{nSv} / \mathrm{h}$.

\section{3. Hydrodynamic cavitation of algal phytomass}

An experimental setup has been mounted and the methodology of research on it - a dynamic type cavitator for the study of the BGA cell wall degradation processes was described to determine the effectiveness of algal biomass pre-treatment in the field of hydrodynamic cavitation [13]. Under cavitation mixing conditions, the effect of algae pre-treatment at the impeller speed of $4000 \mathrm{rpm}$ for $15 \mathrm{~min}$ was compared. After cavitation treatment, the sample was used for lipid extraction and biogas production.

\section{4. Determination of acute toxicity of aqueous solu- tions of algae residues \\ The presence of the acute toxic effect of the aqueous solu-} tions, including the BGA biomass, was determined in accordance with the National Standard of Ukraine "Water Quality. Determination of Acute Lethal Toxicity to Daphnia magna Straus and Ceriodaphnia affinis Lilljeborg (Cladocera, Crustacea)" at the initial concentration resulting within 24 hours to immobilization of $50 \%$ of the total amount of exposed water fleas. This concentration is called "effective initial inhibitory concentration" and referred to as $\mathrm{EC}_{50 \mathrm{n}-24}$. The criterion for the acute lethal toxicity was the death of $50 \%$ or more water fleas in the experiment relative to the control for 24 or 48 hours. The concentrations that caused the death of $50 \%$ or more water fleas during the experiment are called average lethal concentrations and are referred to as $\mathrm{LC}_{50-24}$ or $\mathrm{LC}_{50-48}$.

\section{Blue-green algae as an object of research in} determining the ways of their complex processing

The object of research are BGA (Cyanogenophyta), or, more correctly, cyanogenobacteria (Oxyphotobacteriobion- ta) - the oldest group of autotrophic prokaryotes, the remains of which have been found in Precambrian stromatolites at the age of 2.7-3.2 billion years. Their cosmopolitanism is due to adaptation abilities - ecological plasticity and resistance.

Among them, there are cryophiles (found in the Antarctic ice at $\mathrm{T}=-83^{\circ} \mathrm{C}$ ) and thermophiles (live in hot springs at $\mathrm{T}=+90{ }^{\circ} \mathrm{C}$ ). The reason for this evry smartly tolerance is the polytrophic nature of cyanogenobacteria - the only organisms on the planet, able to assimilate four gases: $\mathrm{CO}_{2}$ for photosynthesis, $\mathrm{O}_{2}$ for breathing, $\mathrm{H}_{2} \mathrm{~S}$ for chemosynthesis and $\mathrm{N}_{2}$ for fixing. During the growing period (70-120 days), one original cell of BGA can produce $10^{20}$ daughter cells, which leads to their mass development - water "bloom".

The results of original research throughout 2002-2016 revealed that the dominant agent of "bloom" of the Kremenchuk and Dniprodzerzhynsk Reservoirs (Ukraine) in the period from the second half of July until the beginning of October is Microcystis aeruginosa (Kützing) Kützing (Fig. 1).

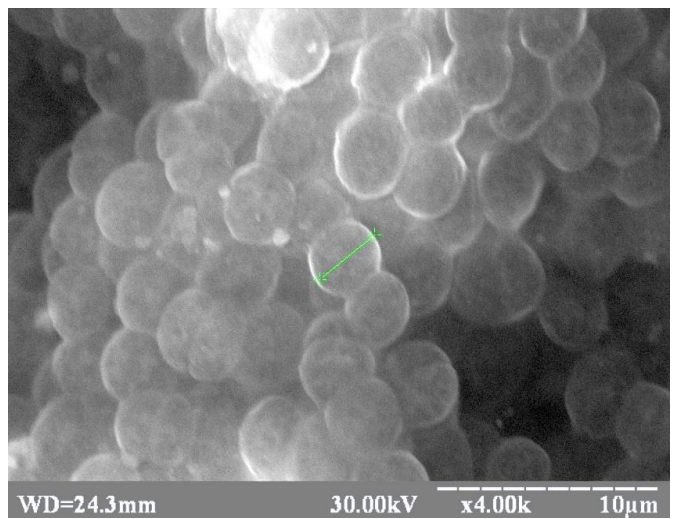

Fig. 1. The scanned image of the Microcystis aeruginosa (Kützing) Kützing colony surface (Electron Microscope SEM-106I, 4000)

During the microscopy, the average diameter of the cells of this type of BGA, which amounted to 3.14 microns was determined.

The results of microscopy have allowed to determine that 95-99\% of the BGA biomass, characteristic of the Kremenchuk and Dniprodzerzhynsk Reservoirs of the Dnieper cascade (Ukraine) is Microcystis aeruginosa (Kützing) Kützing weighing $4 \cdot 14 \cdot 10^{7}$ tons for the growing period (70 days).

\section{Results and discussion}

Thus, the paper set the urgent scientific and practical task - to get the maximum possible amount of energy and useful substances from the BGA biomass (and/or other aquatic organisms). Solutions to this problem, on the whole, are presented in the flow diagram of complex processing of algal biomass (Fig. 2).

Each of the proposed stages is a process or method, relating to environmental and energy sectors of biotechnology, microbiological or chemical industry, forestry and agriculture.

Currently, the method of production of the second (biomethane) and third (bioethanol, or biodiesel) generation biofuels from mass forms of BGA [4, 5], as well as bio-fertilizers (specially prepared after the substrate biomethanogenesis) is known [14]. 


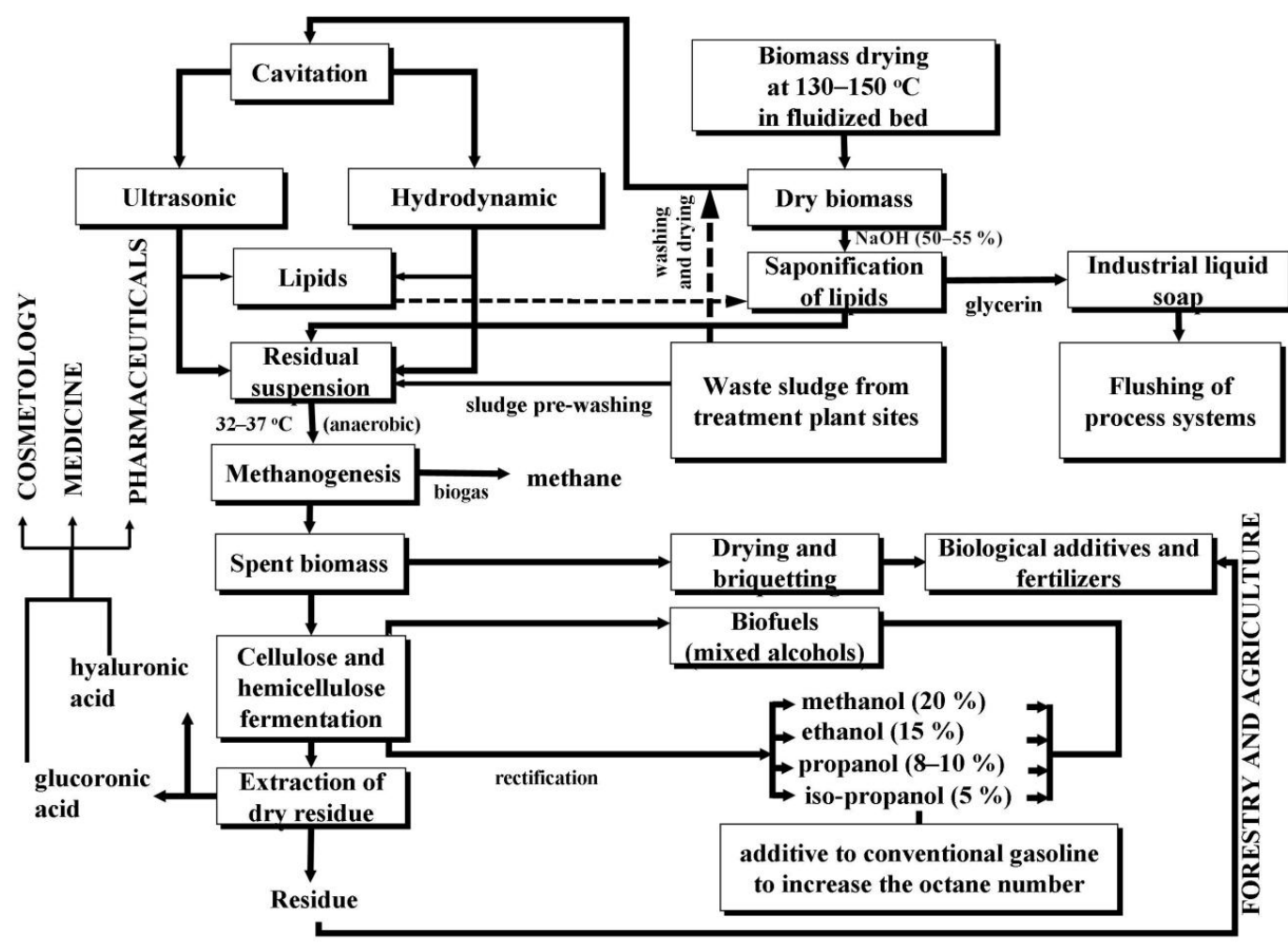

Fig. 2. Biotechnological ways of blue-green algae complex processing and the industries of application of its products

Since 2007, the first and major stages of the BGA biomass deep processing have been tested in the field and laboratory conditions:

a) extraction of lipids after cavitation;

b) allocation of the biogas resulting from methanogenesis;

c) biotesting of the output mineral-organic fertilizer (Fig. 2).

It should be emphasized that BGA are of interest in medicine, pharmacology, cosmetology and perfume industry, because they are a potential source of chromoproteids (complex colored proteins that change their color depending on the absorption spectrum), including phycobiliproteins (red and blue pigments). Hemoproteins, flavoproteins and phycobilins can also be isolated from BGA. The pigments, added to cosmetic compositions improve skin tissue respiration and thus contribute to rejuvenation.

Hyaluronic and glucuronic acids are of particular interest. Their synthesis is very complex from the chemical point of view, therefore, BGA act as a valuable source of these compounds. They are readily removed from residual dry biomass through hydroalcoholic extraction followed by recrystallization at temperatures above $40-50^{\circ} \mathrm{C}$. At higher temperatures, the molecules of these polybasic organic acids lose biological activity, since become racemates or are decarboxylated [15].

\section{1. Extraction of lipids after cavitation}

During desktop studies, four lines of samples of the water suspension of the concentrated BGA biomass (cavitated and without cavitation) before and after methanogenesis were subjected to extraction with carbon tetrachloride. The ex- periments revealed that fresh suspension (without cavitation and before methanogenesis) after extraction for $60 \mathrm{~min}$ is divided into extracted and aqueous phases when using both $\mathrm{CCl}_{4}$ and $\mathrm{CHCl}_{3}$ as extractants, which may be due to the small density of fresh biomass (2.5 times lower than after methanogenesis). The remaining aqueous layer is a suspension, which after drying in the fluidized bed can be used for separating cellulose and hemicellulose.

Despite the fact that the spent biomass density (after the biogas allocation) was half the density of $\mathrm{CCl}_{4}$, phase separation even after 24-hour settling was not observed irrespective of cavitation.

6. 2. Allocation of biogas resulting from methanogenesis

As a result of the biochemical reactions occurring on the organic substrate under the influence of a number of symbiotic microorganisms, the gas mixture was obtained, in which methane accounted for from 65 to $80 \%$, and the rest were carbon and nitrogen oxides, hydrogen sulfide and other gases.

From the chemical point of view, biomethanogenesis includes three stages: dissolution and hydrolysis of organic compounds, acidogenesis and methanogenesis. Accordingly, at each stage there are three groups of bacteria: some (acidogenic) of them convert complex organic substrate compounds to butyric, propionic and lactic acids; other (acetogenic) - turn these organic acids into acetic acid, hydrogen and carbon dioxide, and finally, the methanogenic bacteria recover $\mathrm{CO}_{2}$ to methane with absorption of hydrogen, which might otherwise inhibit the acetic acid bacteria.

In this case, the actual effectiveness of methanogenesis can be determined from the mathematical equation: 


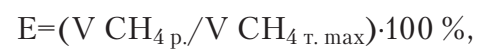

where $\mathrm{V} \mathrm{CH}_{4}$ p. - the amount of methane actually produced from the test BGA biomass sample in a digester, $\mathrm{cm}^{3}$ :

$$
\mathrm{V}_{\mathrm{CH} 4}=\frac{\mathrm{N}_{\mathrm{CH} 4} \mathrm{pT}_{\mathrm{o}} \mathrm{V}_{\text {gasphase }}}{\mathrm{T}_{1} \mathrm{p}_{\mathrm{o}}},
$$

where $\mathrm{N}_{\mathrm{CH} 4}$ - the methane content in a gas phase, \%; $\mathrm{V}_{\text {gas phase }}$ - the gas phase volume in a digester, $\mathrm{dm}^{3} ; \mathrm{T}_{\mathrm{o}}$ - standard temperature $(298 \mathrm{~K}) ; \mathrm{T}_{1}$ - methanogenesis temperature, $\mathrm{K}$; $\mathrm{p}_{\mathrm{o}}$ - standard pressure, $105 \mathrm{~Pa}$; p - reactor pressure, $\mathrm{Pa} ; \mathrm{V} \mathrm{CH}_{4 \text { th max }}$ - theoretical maximum possible volume of methane, $\mathrm{cm}^{3}$ (according to the Clapeyron equation).

Under natural conditions, biogas production is ensured by the vital activity of the mesophilic microflora of digesters. The optimum temperature only due to solar radiation without the use of additional heat sources in most of Ukraine can be rather easily provided in the summer months.

In strictly anaerobic conditions, which can be provided in the process of the cyanogen organic matter bioconversion, methane can be produced from the aromatic compounds that are intermediates of decay of more complex compounds. The total reaction equation in this case is as follows:

$$
4 \mathrm{C}_{6} \mathrm{H}_{5} \mathrm{COOH}+18 \mathrm{H}_{2} \mathrm{O} \rightarrow 15 \mathrm{CH}_{4}+13 \mathrm{CO}_{2} .
$$

It should be noted that the process of methanogenesis is affected by not only the presence of aromatic compounds, but also acyclic carboxylic acids such as propionic, acetic, butyric acids. Their anaerobic digestion also gives additional hydrogen, which ultimately increases the methane yield:

$$
\begin{aligned}
& \mathrm{C}_{2} \mathrm{H}_{5} \mathrm{COOH}+3 \mathrm{H}_{2} \mathrm{O} \rightarrow \\
& \rightarrow \mathrm{CH}_{3} \mathrm{COOH}+\mathrm{HCO}^{3-}+3 \mathrm{H}_{2}+3 \mathrm{H}^{+}, \\
& \mathrm{C}_{3} \mathrm{H}_{7} \mathrm{COOH}+2 \mathrm{H}_{2} \mathrm{O} \rightarrow \\
& \rightarrow 2 \mathrm{CH}_{3} \mathrm{COOH}+2 \mathrm{H}_{2}+\mathrm{H}^{+} .
\end{aligned}
$$

An experimental setup to simulate the methanogenesis process in experimental and laboratory conditions was mounted and tested in the laboratory of Bioenergy at the Department of Natural Sciences, enhanced and put into operation on the basis of the laboratory of the Biotechnology and Human Health Department of the Kremenchuk Mykhailo Ostrohradskyi National University (Ukraine). The experiment was conducted in a dry air electric thermostat TS- $80 \mathrm{M}$ at a temperature of $+30{ }^{\circ} \mathrm{C}$.

Two cyanogen biomass samples $(\mathrm{V}=$ $\left.=0.5 \mathrm{dm}^{3}\right)$, selected in the urban area of the Dniprodzerzhynsk Reservoir (near the "Neptune" Basin) in September 2015 were used in the experiment. Based on the data from a number of studies [16-18], determining the cyanogenobacteria biomass pretreatment efficiency using the hydro-mechanical methods, one of the samples was previously subjected to a mechanical cavitation procedure for $7.5 \mathrm{~min}$.
A day after the start of the experiment, the emission of the first volumes of the biogas collected in the corresponding measuring cylinders by the "water seal" method was recorded (Fig. 3).

As a result of methanogenesis for 37 days, $1.72 \mathrm{dm}^{3}$ of biogas were produced from $1 \mathrm{dm}^{3}$ of the non-cavitated substrate. Pre-cavitation increases the biogas volume to $2.19 \mathrm{dm}^{3}$ (by $21.5 \%$ ). These samples have been analyzed by the Crystal-2000M gas chromatograph, which gave grounds for determining the chemical composition (Table 1), density and calorific value of the gas mixture.

In the next stage of research, the calorific value of the biogas produced to be $33 \mathrm{MJ} / \mathrm{m}^{3}$ was determined experimentally. The biogas density was in the range of $0.914-0.922 \mathrm{~kg} / \mathrm{m}^{3}$ and calorific value $\mathrm{Q}=5100-5200 \mathrm{~kJ} / \mathrm{m}^{3}$.

Thus, the physical and thermodynamic parameters of the biogas produced are close to those of the natural gas - propane-butane mixture. The latter can be used for heating industrial and residential buildings.

The research resulted in the design, installation and testing of the laboratory setup, simulating the biomethanogenesis process using different types of substrates in natural temperature conditions and in the isothermal model systems. This approach is expedient when using the cyanogen concentrated organic matter as a substrate for biogas plants on an industrial scale. To collect a substrate on an industrial scale, special concentration columns are placed in the areas of maximum natural concentration of the blue-green algae biomass (Fig. 4) [14].

The proposed process flow diagram of the biogas production (Fig. 4) is based on an intermittent feed of a substrate in a concentration column [14]. In this case, the algal biomass is fed by gravity. Biomass floats to the surface due to the presence of gas bubbles therein, and clean water remains on the column bottom. As soon as the lower level of the biomass reaches a distribution valve, it is switched to feed the biomass in a digester to carry out methanogenesis. The remaining substrate is removed from the anaerobic chamber and sent for drying or briquetting to produce a biofertilizer. A part of the spent substrate from a digester contains methanogenic microbiocenosis, therefore is further used as seed stock for inoculation of feeding in the next sestonic biomass fermentation cycle.

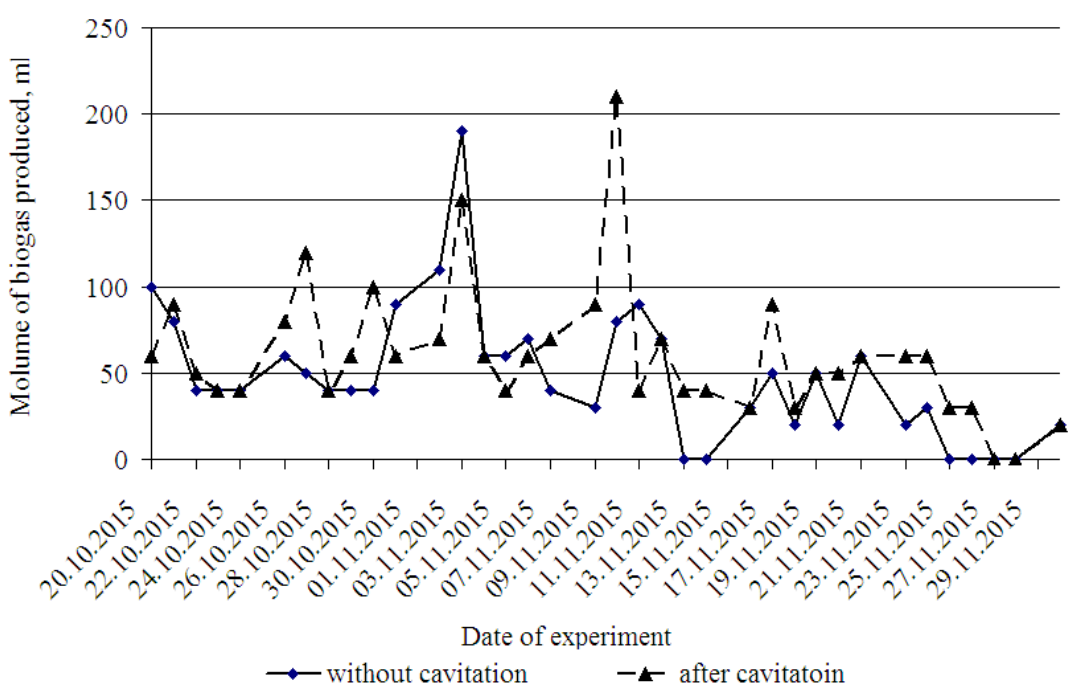

Fig. 3. Dynamics of biogas allocation from the BGA biomass 




Fig. 4. The layout of process units of the biogas plant

Table 1

The chemical composition of the biogas ( $\%)$, produced from cyanogens during November 2015

\begin{tabular}{|c|c|c|c|c|c|c|c|c|}
\hline No & date & $\mathrm{CH}_{4}+\mathrm{H}_{2}$ & $\mathrm{CO}_{2}$ & $\mathrm{~N}_{2}$ & $\mathrm{O}_{2}$ & $\mathrm{CO}$ & $\mathrm{H}_{2} \mathrm{~S}$ & others \\
\hline 1 & 2 & 3 & 4 & 5 & 6 & 7 & 8 & 9 \\
\hline 1 & 02.11 & 70.10 & 20.05 & 8.15 & 0.36 & 0.15 & 0.04 & 1.15 \\
\hline 2 & 03.11 & 72.00 & 19.07 & 7.05 & 0.49 & 0.22 & - & 1.17 \\
\hline 3 & 04.11 & 71.75 & 20.77 & 6.75 & 0.73 & - & - & - \\
\hline 4 & 05.11 & 71.90 & 20.00 & 7.23 & 0.43 & 0.22 & - & 0.22 \\
\hline 5 & 06.11 & 70.14 & 22.04 & 7.34 & 0.34 & 0.11 & 0.03 & - \\
\hline 6 & 07.11 & 71.15 & 21.05 & 7.30 & 0.33 & 0.12 & - & 0.05 \\
\hline 7 & 09.11 & 73.09 & 20.14 & 6.13 & - & 0.54 & - & 0.10 \\
\hline 8 & 10.11 & 72.05 & 19.05 & 7.02 & 0.03 & 0.02 & 0.09 & 1.74 \\
\hline 9 & 11.11 & 70.30 & 21.05 & 7.25 & 0.80 & 0.60 & - & - \\
\hline 10 & 12.11 & 71.11 & 20.01 & 6.30 & 0.55 & - & - & 2.03 \\
\hline 11 & 13.11 & 73.00 & 19.11 & 5.98 & 0.30 & 0.29 & - & 1.32 \\
\hline 12 & 14.11 & 71.15 & 20.05 & 5.41 & 0.18 & 0.10 & - & 3.11 \\
\hline 13 & 16.11 & 71.56 & 20.28 & 6.02 & 0.42 & 0.16 & - & 1.56 \\
\hline 14 & 17.11 & 71.74 & 19.95 & 7.31 & 0.59 & 0.27 & - & 0.14 \\
\hline 15 & 18.11 & 70.25 & 20.21 & 5.47 & 0.85 & 0.15 & 0.07 & 3.00 \\
\hline 16 & 19.11 & 72.77 & 19.18 & 6.12 & 0.27 & 0.13 & - & 1.53 \\
\hline 17 & 20.11 & 70.26 & 21.09 & 6.54 & 0.21 & 0.23 & - & 1.67 \\
\hline 18 & 21.11 & 72.05 & 19.54 & 7.00 & 0.48 & 0.25 & - & 0.68 \\
\hline 19 & 23.11 & 69.78 & 22.87 & 5.97 & 0.35 & - & - & 1.03 \\
\hline 20 & 24.11 & 67.99 & 24.14 & 6.18 & 0.30 & 0.18 & - & 1.21 \\
\hline 21 & 25.11 & 72.54 & 19.91 & 5.11 & 0.41 & 0.09 & - & 1.94 \\
\hline 22 & 26.11 & 70.97 & 20.10 & 7.00 & 0.43 & 0.11 & - & 1.39 \\
\hline 23 & 27.11 & 73.25 & 18.88 & 5.01 & 0.55 & - & - & 2.31 \\
\hline 24 & 28.11 & 72.14 & 19.14 & 6.05 & 0.61 & 0.21 & - & 1.85 \\
\hline 25 & 30.11 & 70.23 & 21.13 & 5.55 & 0.40 & 0.24 & 0.05 & 2.40 \\
\hline$\Sigma_{\text {avg. }}$ & - & 71.33 & 20.35 & 6.45 & 0.42 & 0.18 & 0.01 & 1.26 \\
\hline
\end{tabular}

6. 3. Opportunities for production of mineral-organic fertilizer from the spent substrate of blue-green algae

The next stage of research was based on the need for further processing of the spent substrate remaining after methanogenesis. The conventional technology of biogas production in economically feasible quantities involves the use of waste of agriculture, primarily livestock as an organic substrate. In this case, the biogas technology allows producing natural biofertilizers, containing biologically active substances and microelements by means of anaerobic fermentation. Their main advantage over traditional fertilizers is the form, availability and balance of all nutrients, high levels of organic matter humification. Therefore, the introduction of such biofertilizers in the soil activates nitrogen-fixing and other microbiological processes.

Thus, the use of the substrate spent in methanogenesis (organic matter) as a fertilizer in agriculture and forestry can be regarded as a promising waste-free biotechnological direction.

In this respect, the study of the dynamics of quantitative germination of model organisms (test objects), typically agricultural crops, is a priority in determining the efficiency of the spent substrate impact on plants. To determine the seed germination rate as a criterion for assessing the possibility of using blue-green algae after methanogenesis, two species of crops: soft wheat - Triticum durum L. (monocotyledons) and pea - Pisum sativum L. (dicotyledons) were used as fertilizers.

Seed germination of the test objects was carried out in petri dishes using the spent substrate at different dilutions $(1: 10,1: 50,1: 100,1: 200,1: 500$ and $1: 1000)$ at $\mathrm{T}=25^{\circ} \mathrm{C}$ and $\mathrm{pH}=6.5-7.50$. Germinating ability was determined by the number of germinated seeds out of $100(\%)$ as compared with the control (double-distilled water irrigation) in triplicate.

The analysis of the results of studies on the pea and wheat germination on substrates with different concentrations revealed that the highest germination rate of wheat is at 1:100 and 1:200 dilutions of the substrate, and pea - at 1:50 and 1:100. Thus, 1:100 dilution of the spent substrate is optimum for using the algae residues as bio-fertilizers in agriculture and forestry. 
Proceeding from the fact that biotesting is an integral part of quality assessment and control of aqueous solutions of various industrial purposes, a number of diluted cyanogen substrates spent in the biogas production with different concentrations were subjected to biotesting in accordance with the National Water Quality Standard. The basic technique of the experiment provides for the use of crustaceans - cladocerans Daphnia magna Straus as a test object.

A thorough analysis of the results of studies of survival rate of water fleas in the substrate aqueous solutions with different concentrations allowed us to determine their levels of toxicity:

- the survival rate of test objects in the control is absolute;

- the survival rate of water fleas at 1:10 and 1:50 dilutions of the spent substrate decreased by 90 and $76 \%$, respectively;

- the survival rate of water fleas at 1:10 and 1:50 dilutions of fresh (toxic) substrate decreased by 93 and $83 \%$, respectively;

- the survival rate of test objects at 1:100, 1:200, 1:500, 1:1000 dilutions of fresh (toxic) spent substrates ranged from 90 to $100 \%$.

Thus, dilutions starting with 1:100 are optimum for the use of substrates as bio-fertilizers, which is fully consistent with the biotesting results using model organisms of peas and wheat.

The feasibility of using the cyanogen spent biomass was also confirmed by the results of measurements of the mass fraction (\%) of the basic chemical elements using the EXPERT 3L XRF analyzer (Table 2), the values of which correlate with the elemental qualitative and quantitative composition of living plant cells.

Table 2

Mass fraction of chemical elements of the cyanogenobacteria biomass after methanogenesis with the content of $>1 \%$

\begin{tabular}{|c|c|c|c|}
\hline \multirow{2}{*}{ Chemical element } & \multicolumn{3}{|c|}{ Mass fraction, \% } \\
\cline { 2 - 4 } & sample 1 & sample 2 & average \\
\hline${ }_{15} \mathrm{P}$ & $7.47 \pm 0.30$ & $7.16 \pm 0.13$ & $7.32 \pm 0.22$ \\
\hline${ }_{16} \mathrm{~S}$ & $10.10 \pm 0.22$ & $11.71 \pm 0.10$ & $10.91 \pm 0.16$ \\
\hline${ }_{17} \mathrm{Cl}$ & $9.45 \pm 0.19$ & $8.46 \pm 0.08$ & $8.96 \pm 0.14$ \\
\hline${ }_{14} \mathrm{Si}$ & $3.75 \pm 0.18$ & $4.43 \pm 0.09$ & $4.09 \pm 0.14$ \\
\hline${ }_{19} \mathrm{~K}$ & $21.41 \pm 0.14$ & $20.20 \pm 0.06$ & $20.81 \pm 0.10$ \\
\hline${ }_{20} \mathrm{Ca}$ & $44.54 \pm 0.25$ & $45.13 \pm 0.11$ & $44.84 \pm 0.18$ \\
\hline${ }_{25} \mathrm{Mn}$ & $1.46 \pm 0.03$ & $1.14 \pm 0.02$ & $1.30 \pm 0.03$ \\
\hline${ }_{26} \mathrm{Fe}$ & $1.69 \pm 0.03$ & $1.49 \pm 0.02$ & $1.59 \pm 0.03$ \\
\hline
\end{tabular}

The results indicate that the elemental composition of the cyanogenobacteria biomass after methanogenesis is similar to the elemental composition of the green mass of plants. Therefore, the BGA spent substrate can be used as a biofertilizer, because it is similar in nutritional value.

\section{4. Production of biologically active substances from cyanogens}

Earlier studies [17] found that $1 \mathrm{~kg}$ of dry microcystis biomass contains $320 \mathrm{~g}$ of carbohydrate, $300 \mathrm{~g}$ of protein, $5 \mathrm{~g}$ of fat, $3.8 \mathrm{mg}$ of thiamine, $3.7 \mathrm{mg}$ of nicotinic acid, $0.9 \mathrm{mg}$ of pyridoxine and $0.1 \mathrm{mg}$ of biotin. Hydrolysis of proteins and polysaccharides produced 17 amino acids and 11 monosaccharides, respectively. It is also known that the maximum "bloom" of natural population of Microcystis aeruginosa (Kützing) Kützing of the Kremenchuk Reservoir (Ukraine) is accompanied by the highest content of carbohydrates and vitamins in the biomass.

Proteins. Mass forms of BGA synthesize a significant amount of proteins and proteids (more than $30-40 \%$ of dry matter) as a result of their vital activity.

An important fact is that the BGA proteins include almost all natural amino acids: cysteine, arginine, serine, glycine, tyrosine, methionine, valine, isoleucine, lysine, histidine, threonine, alanine, phenylalanine, leucine, aspartic and glutamic acid. This testifies to their balanced amino acid composition.

The latter seven are in the highest quantities. BGA proteins include all of the essential amino acids, constituting 45-50\% of the total amount of amino acids.

Carbohydrates. The BGA species, causing the "bloom" of reservoirs are active producers of large quantities of various polysaccharides, especially hemicellulose and pectin, constituting $35-40 \%$ of the amount of carbohydrates, which, in turn, reach $30 \%$ of the dry algal matter.

BGA accumulate specific-type glycogen polymer, forming a glycoprotein with proteins, as a reserve polysaccharide. The BGA polysaccharides include glucose, arabinose, rhamnose, fructose, galactose, fucose, xylose, mannose and uronic acids.

Of special interest are the BGA sulfopolysaccharides involved in the ion exchange process and having the gel forming ability. Their content can reach $30 \%$.

Fats. Mass forms of BGA accumulate a small amount of lipids - up to $5 \%$. However, their hydrolyzate contains a wide variety of higher fatty acids with a prevalence of saturated forms. The BGA lipids have an antibacterial effect and are of particular interest in this respect.

Phosphororganics. The BGA, dominant in the Dnieper reservoirs are rich in phosphorus and contain inorganic phosphate, phosphoric esters of saccharides, mono-, diand triphosphonucleotides, nucleic acids, phospholipids, and high molecular weight polyphosphates. These compounds can be obtained in significant quantities during BGA complex processing.

Vitamins. Another group of biologically active substances (BAS), synthesized by BGA are vitamins. Of particular interest among them are nicotinic acid, thiamine, pyridoxine, biotin and cobalamin.

Thus, BGA are a source of biologically active substances that can be used not only in agriculture for feed vitaminization, but also for biotechnological and nano processes. Herewith, biologically active substances of BGA in microquantities can be purposefully delivered to specific cells of tissues and organs using magnetic particles - the carriers of BAS - for the desired therapeutic effect. However, this unit requires additional targeted research.

\section{Conclusions}

1. The research using standardized methods of light and electron microscopy revealed that the main type of blue-green algae of the Kremenchuk and Dniprodzerzhynsk reservoirs of the Dnieper cascade (Ukraine) is Microcystis aeruginosa (Kützing) Kützing weighing $4.14 \cdot 10^{7}$ tons during the growing season. The average diameter of the BGA cells was 3.14 microns. 
2. Gas chromatography found that the biogas produced by the cyanogenobacteria biomass methanogenesis is a mixture of gaseous components containing both primary components of methane and hydrogen (in total) up to $72 \%$, carbon dioxide - up to $20 \%$, molecular nitrogen - up to $6.5 \%$, respectively. Preliminary mechanical cavitation of the biomass increases the methane yield by $21.5 \%$.

3 . It was proved that algae residues can be used as biofertilizers in agriculture and forestry as a substrate aqueous solution at 1:100, 1:200, 1:500, 1:1000 dilutions, the survival rate of cladocerans Daphnia magna Straus as test objects is from 90 to $100 \%$. The optimum concentration of the spent substrate aqueous solution depends on the methanogenesis process completeness. The data of the $\mathrm{X}$-ray diffraction analysis confirmed the compliance of the elemental composition of the spent substrate with the green mass of plants, which will provide a high nutritional value of algae residues.

4. A full-scale diagram of biotechnological ways of bluegreen algae complex processing was proposed, and the industries of application of its products were identified, which determines the directions of further research.

\section{References}

1. Rajeshwari, K. R. Biochemical composition of seven species of cyanobacteria isolated from different aquatic habits of Western Ghats, Southern India [Text] / K. R. Rajeshwari, M. Rajashekhar // Brazilian archives of biology and technology. - 2011. - Vol. 54, Issue 5. - P. 849-857. doi: 10.1590/s1516-89132011000500001

2. Mussgnug, J. H. Microalgae as substrates for fermentative biogas production in a combined biorefinery concept [Text] / J. H. Mussgnug, V. Klassen, A. Schluter, O. Kruse // Journal of Biotechnology. - 2010. - Vol. 150, Issue 1. - P. 51-56. doi: 10.1016/ j.jbiotec.2010.07.030

3. Hoiczyk, E. Cyanobacterial cell walls: news from an unusual prokaryotic envelope [Text] / E. Hoiczyk, A. Hansel // Journal of bacteriology. - 2000. - Vol. 82, Issue 5. - P. 1191-1199. doi: 10.1128/jb.182.5.1191-1199.2000

4. Da Ros, P. C. M. Assessment of chemical and physico-chemical properties of cyanobacterial lipids for biodiesel production [Text] / P. C. M. Da Ros, C. S. P. Silva, M. E. Silva-Stenico, M. F. Fiore, H. F. De. Castro // Marine drugs. - 2013. - Vol. 11, Issue 7. P. 2365-2381. doi: 10.3390/md11072365

5. Ehimen, E. A. Anaerobic digestion of microalgae residues resulting from the biodiesel production process [Text] / E. A. Ehimen, Z. F. Sun, C. G. Carrington, E. J. Birch, J. J. Eaton-Rye // Applied Energy. - 2011. - Vol. 88, Issue 10. - P. 3454-3463. doi: 10.1016/ j.apenergy.2010.10.020

6. Sirenko, L. A. Aktivnost solntsa i «tsvetenie» vodyi [Text] / L. A. Sirenko // Gidrobiologicheskiy zhurnal. - 2002. - Vol. 38, Issue 4. - P. 3-9.

7. Dzyuban, A. N. Sezonnaya dinamika mikrobiologicheskogo tsikla metana v vode pribrezhnyih melkovodiy Ryibinskogo vodohranilischa [Text] / A. N. Dzyuban // Gidrobiologicheskiy zhurnal. - 2006. - Vol. 42, Issue 6. - P. 47-51.

8. Ramochnaya konventsiya OON po izmeneniyu klimata [Electronic resource]. - Rio-de-Zhaneyro, 1992. - Available at: http://www. un.org/ru/documents/decl_conv/conventions/climate_framework_conv.shtml

9. Direktiva 2000/60/ES Evropeyskogo Parlamenta i Soveta «Ob ustanovlenii ramok deyatelnosti Soobschestva v oblasti vodnoy politiki» [Electronic resource]. - Bryussel, 2000. - Available at: http://search.ligazakon.ua/l_doc2.nsf/link1/MU00298.html

10. Tselevaya kompleksnaya programma nauchnyih issledovaniy NAN Ukrainyi «Biomassa kak toplivnoe syire» [Electronic resource]. Available at: http://search.ligazakon.ua/1_doc2.nsf/link1/MUS14756.html

11. Rastrovyj ehlektronnyj mikroskop REM-106 [Electronic resource]. - Availableat:http://www.ukrrospribor.com.ua/?me=21\&id=360

12. Mobil'nyj precizionnyj analizator Expert 3L [Electronic resource]. - Available at: http://inam.kiev.ua/expert-3l/

13. Malovanyy, M. Mathematical model of the process of synthesis of biogas from blue-green algae [Text] / M. Malovanyy, V. Nykyforov, O. Kharlamova, O. Synelnikov // Ecological Safety. - 2015. - Vol. 1, Issue 19. - P. 58-63.

14. Patent na korisnu model no.104743 (Ukraine) Sposib virobnitstva metanu ta dobriva [Text] / Nykyforov V. V., Elizarov M. O., Pasenko A. V., Digtyar S. V., Shlik S. V. - u2015 09476; decelerated: 08.10.2015; puublished: 10.02.2016; Bul. 3. - 3 p.

15. Ratushnaya, M. Ya. O himicheskom sostave nekotoryih sinezelyonyih vodorosley [Text] / M. Ya. Ratushnaya, L. V. Kosenko, A. S. Kirillov, V. S. Sokoda // Mikrobiologiya. - 1967. - Vol. 29, Issue 1. - P. 3-33.

16. Nykyforov, V. V. O prirodoohrannyih i energosberegayuschih perspektivah ispolzovaniya sinezelenyih vodorosley [Text] / V. V. Nykyforov // Promyishlennaya botanika. - 2010. - Vol. 10. - P. 193-196.

17. Malovanyy, M. Reduction of the environmental threat from uncontrolled development of cyanobacteria in the waters of the Dnieper reservoirs [Text] / M. Malovanyy, V. Nykyforov, O. Kharlamova, A. Synelnikov, Kh. Dereyko // Environmental problems. - 2016. Vol. 1, Issue 1. - P. 61-64.

18. Nykyforov, V. V. Gidrobiontyi kak novyiy substrat dlya polucheniya klar-gaza [Text] / V. V. Nykyforov, T. F. Kozlovskaya, S. V. Degtyar // Ekologichna bezpeka. - 2008. - Vol. 3, Issue 3. - P. 28-30. 